\title{
СТАНОВЛЕНИЕ УГОЛОВНОГО ЗАКОНОДАТЕЛЬСТВА ФРГ ОБ ОТВЕТСТВЕННОСТИ ЗА ПРЕСТУПЛЕНИЯ ПРОТИВ ПОЛОВОГО САМООПРЕДЕЛЕНИЯ ДЕТЕЙ И МОЛОДЕЖИ
}

\section{FORMATION OF THE CRIMINAL LEGISLATION OF THE FEDERAL REPUBLIC OF GERMANY ON RESPONSIBILITY FOR CRIMES AGAINST SEXUAL SELF-DETERMINATION OF CHILDREN AND YOUTH}

\section{Sayfullina \\ Ammar Abdul Karim Manna}

Summary: The article deals with the problem of the formation of the FRG criminal legislation in the field of protecting children and young people from sexual abuse. The norms of Criminal Law Reform Act (Strafrechtreformgesetzte), as well as criminal law amendment act (Strafrechtsaenderungsgtsetze) are also analysed. They were adopted during the period of institution reforms. The author shows that a number of provisions were introduced under the influence of international norms, requirements and decisions of the European Union.

Keywords: the Federal Republic of Germany criminal legislation, sexual abuse of children and youth, criminal Law Reform act, criminal law amendment act, indecent assault.
Сайфуллина Мария Ивановна

Российский университет дружбы народов (РУДН)

mari.sajfullina@bk.ru

Аммар Абдуль Карим Манна

К.ю.н., дочент, Российский университет дружбы народов

(РУДН)

amar0606@mail.ru

Аннотация: В статье освящается проблема становлении уголовного законодательства ФРГ в сфере защиты детей и молодежи от сексуальных злоупотреблений. Анализу подвергаются нормы законов о реформе уголовного права (Strafrechtreformgesetzte), а также законов об изменении уголовного права (Strafrechtsaenderungsgtsetze), принятых в период реформ исследуемого института. Автор показывает, что ряд положений были внесены под влиянием международных норм, а также требований Европейского Союза и его решений.

Ключевые слова: уголовное законодательство ФРГ, сексуальные злоупотребления в отношении детей и молодежи, сексуальное насилие над детьми, законы о реформе уголовного права, законы об изменении уголовного права.

\section{Введение}

$\Gamma$ лобальной проблемой как для мирового сообщества, так и для отдельных государств является сексуальное насилие в отношении детей и молодежи, потому что деформация психического и физического развития детей и молодежи угрожает здоровью нации не только отдельной страны, но и всего человечества в целом.

В ФРГ, несмотря на то что федеральное законодательство в сфере защиты детей и молодежи от сексуального насилия интенсивно реформируется, количество преступлений остается стабильно высоким. Так, по данным полиции, в 2019 году жертвами сексуального насилия стали 15701 ребенок [1]. Новым вызовом для правоохранительных органов Германии становится использование цифровых медиа и даркнет при создании детской порнографии и распространении её в Сети Интернет. Именно поэтому Йоханнес-Вильгельм Рёриг, комиссар федерального правительства ФРГ, указал: «Борьба с такими злоупотреблениями и их последствиями в Германии должна наконец рассматриваться как общенациональ- ная задача» [2].

Авторы поставили целью научной статьи сформировать представление о формировании норм об ответственности за сексуальные злоупотребления в отношении детей и молодежи в ФРГ на основе российской и немецкой юридической литературы и анализа нормативной базы.

\section{Методы}

Методологической основой данной статьи являются система методов и приемов научного познания, характерных для науки правоведения.

В ходе исследования применялись следующие методы познания: исторический, позволивший выявить особенности становления уголовного законодательства ФРГ в сфере охраны полового самоопределения детей и молодежи; использование сравнительно-правового метода для изучения становления института охраны полового самоопределения детей и молодежи в ФРГ в связи с конкретной исторической и правовой обстановкой; 
формально-юридический метод применялся при анализе Уголовного уложения ФРГ и иных нормативных актов с целью уяснения их сути и значимости. В ходе сравнения использовался также аналитическо-сравнительного метод, предполагающий не только анализ сопоставленного правового материала, но и определенные выводы из сравнений.

\section{Результаты}

Защита детей и молодежи от сексуального насилия является приоритетным направлением деятельности Правительства Германии. Уголовное законодательство ФРГ в сфере защиты от сексуальных посягательств детей и молодежи основывается на общепризнанных принципах международного права, но в тоже время постоянно подвергается реформированию. Так, существенные изменения в Уголовное Уложение ФРГ вносились путем принятия законов о реформе уголовного права (Strafrechtreformgesetzte) 1969г., 1998г.изаконов об изменении уголовного права (Strafrechtsaenderungsgtsetze) 1993 г., 1998 г., 2003 г., 2008 г., 2013 г., 2015 г., 2020 г. Проведя анализ данных нормативных актов, необходимо отметить, что на становление института защиты детей и молодежи от сексуальных посягательств также влияли требования Европейского Союза и его решения. Подчеркнем: ряд законотворческих инициатив, например либерализация уголовного законодательства 1994 года, были приняты под политическим давлением.

\section{Обсужмение}

Сексуальное насилие в любой форме наносит тяжелую физическую и психологическую травму ребенку, поэтому видные ученые: Фолькмар Сигуш, Клаус Михаэль Байер, Ульрих Вебер - справедливо указывают: защита детей от всех форм сексуального посягательства на половую неприкосновенность является приоритетным направлением деятельности любого государства. В 1991 году комитет министров Совета Европы принял «Рекомендацию о сексуальной эксплуатации, порнографии, проституции и торговле детьми и несовершеннолетними», в которой указывалось на необходимость проведения государствами исследования связей между секс-индустрией и организованной преступностью, приведение в соответствие национальных законодательств в сфере борьбы с сексуальной эксплуатацией детей, а также было рекомендовано странам вводить соответствующие уголовные санкции за исследуемые деяния.

5 апреля 1992 года ФРГ ратифицировала Конвенцию «О правах ребенка», нормы которой обязывали государства принимать все необходимые меры с целью защиты ребенка от всех форм физического и психического насилия (ст.19), а также защищать права детей от сексуального насилия и сексуальной эксплуатации (ст.34).
Исследуемый правовой институт, как и все уголовное право Германии, на протяжении длительного времени подвергался реформированию. Стоит отметить, что еще в Уу 1871 г. предусматривалась уголовная ответственность за совершение непристойных действий с лицом в возрасте 14 лет, либо за побуждение к совершению таких действий, либо принуждение терпеть непристойные действия.

Основные изменения в исследуемый институт вводились путем принятия либо законов о реформе уголовного права (Strafrechtreformgesetzte), либо законов об изменении уголовного права (Strafrechtsaenderungsgtsetze), а также иными федеральными законами. Так, первый и второй законы о реформе уголовного права (BGBI), принятые 25.06 и 04.07.1969 года, изменили название 13 раздела УУ ФРГ «Преступление против морали» на «Преступлениях против сексуального самоопределения» [3, с.645; 4, с.717]. Согласно четвертой поправке в УУ ФРГ 1973 года, термин «защита социальной нравственности ребенка» переквалифицируется на «защиту ребенка», а «развратные действия» - на «сексуальное насилие» [5, c.1725]. Защита детей от сексуального злоупотребления была предусмотрена в § 176 УУ ФРГ. Следует отметить, что данное деяние рассматривалось либо как уголовный проступок, либо как преступление, это связано было с формальным признаком. Санкция по данной статье предусматривала лишение свободы на срок от шести месяцев до десяти лет, а, в соответствии с ч.2. ст. 12 уУ ФРГ, уголовный проступком признавались деяния, за которые была предусмотрена санкция в виде лишения свободы менее чем на один год или денежный штраф.

23 июля 1993 года вступил в действие 27-й Закон об изменении Уголовного кодекса ФРГ (BGBL I.S. 1346), внесший существенные поправки в ряд статей: так, в абз.1 и 3 \$174 в качестве потерпевших признавались опекаемые лица; абз.1-4, 5 N 2 и 6 §176 предусмотрели уголовную ответственность граждан ФРГ за сексуальные злоупотребления - «истязание» в отношении детей, совершаемых за границей, независимо от национального законодательства того государства, где было совершено преступление. Эта же диспозиция действовала в §176 независимо от гражданства потерпевшего. [6, с.1346].

В рамках либерализации уголовного законодательства ФРГ 31 мая 1994 г был исключен §175, предусматривавший ответственность за гомосексуальные действия с мужчиной младше 18 лет [7, с.1168]. Стоит отметить, до 1969 года уголовная ответственность наступала за однополый сексуальный контакт, независимо от возраста мужчин. Однако в после реформы уголовного права 1969 года субъектом преступления мог быть только мужчина, достигший 21-летнего возраста [4, с.717]. В 1973 году возраст был снижен до 18 лет, но суд мог освободить от уголовной ответственности (преследования) 
лицо, не достигшее 21 года, в случае неподобающего поведения потерпевшего либо незначительности неправомерного деяния. Новая редакция § 182 предусмотрела охрану 14-15 летних подростков, независимо от пола, от сексуального действия от лиц, использовавших их зависимое положение.

Следующая, 30-я поправка в Уголовный кодекс ФРГ ввела норму (§ 78b) о приостановлении срока давности уголовного преследования половых преступных деяний, совершенных в отношении детей и молодежи до достижения восемнадцатилетнего возраста [8.].

В 1996 году на Первом Всемирном конгрессе по борьбе коммерческой сексуальной эксплуатации детей были приняты Стокгольмская декларация и План действий. В документе указывалось, что коммерческая сексуальная эксплуатация (КСЭД) является формой принуждения детей и насилия над ними. Ребенок становится сексуальным и коммерческим предметом. В Декларации были выделены такие формы КСЭД, как проституция, порнография и трэффик, т.е. сексуальная эксплуатация детей во время деловых или туристических поездок, и ранний брак.

Существенные изменения в уу ФРГ были внесены 33-й поправкой. Так, были объединены две статьи §177 и §178 «Изнасилование» и «Принуждение к сексуальным отношениям» в одну - \$177 «Принуждение к сексуальным действиям: изнасилование», т.е. законодатель поддержал доктрину уголовного права ФРГ, основывающуюся на том, что изнасилование необходимо рассматривать как квалифицированный вид сексуального принуждения [9, с.1607]. В действующей редакции к особо тяжким случаям сексуального принуждения было отнесено изнасилование с применением особенно унизительных сексуальных действий. Под санкцию §177 УУ ФРГ статьи подпадали лица, злоупотреблявшие своим положением и совершавшие деяния в отношении беззащитной жертвы. В новой редакции потерпевшим мог быть как мужчина, так и женщина, независимо от семейного положения.

Важным шагом в сфере защиты детей от сексуального насилия стал третий этап реформы уголовного права ФРГ. Так, шестой Закон о реформе уголовного права ужесточил уголовно-правовую защиту детей § 176-176b уу ФРГ [10, с. 164]: в простом составе § 176 УУ ФРГ была повышена санкция; значительно расширен состав § 176а тяжкие сексуальные действия в отношении детей; предусмотрен рецидив в абз. 1 № 4; введено в ст. 177 УУ ФРГ два квалифицированных состава: принуждение к сексуальным действиям и изнасилование, повлекшее смерть жертвы по легкомыслию (абз.3 и 4). Данные деяния были признаны тяжелейшей формой состава преступления, за которые была предусмотрены санкции в виде пожизненного лишения свободы либо лишение свободы на срок не менее десяти лет. В диспозицию абз.1 179 уУ ФРГ был введен такой признак потерпевшего, как наличие умственной или душевной болезни либо мании, и ужесточена санкция. В соответствии с обз.2 § 179 УУ ФРГ, жертвами также признавались пациентки и пациенты, вверенные обвиняемому для психотерапевтического лечения.

Нормы Закона «О борьбе с сексуальными деликтами и иными опасными преступными деяниями» от 26.01. 1998 года предусмотрели санкцию - применение превентивного заключения в отношении виновных, совершивших сексуальный проступок, и установление надзора над такими лицами, в случае несогласия осужденного пройти курс лечения [11, с.160]. На основании данного закона были введены изменения в Закон о исполнении наказания [12, с.161]. Так, лицо, осужденное за деяния, предусмотренные § 174-180, 182 УУ ФРГ (лишение свободы на срок более двух лет), по решению суда могло быть помещено в социально-терапевтическое учреждение без его согласия для проведения обследования. Это вызвало многочисленные жалобы, например: кассационную жалобу на решение районного суда в областной суд Дрессау от 20 октября 1998 г. и решение об отклонении жалобы ответчика Мюнхенского областного суда 15 декабря 2008 г. о помещении его в психиатрическую больницу в соответствии с ст.63 УУ ФРГ [13.].

Наиболее существенные поправки в исследуемый институт были внесены Законом «О внесении изменений и положений о преступлениях половой неприкосновенности» от 27 декабря 2003 года [14, с.3007], основной целью которого стало введение более жестких санкций за покушение сексуального характера в отношении детей и за совершения действий сексуального характера, предусмотренные в § 174-174с и 179 УК ФРГ. В диспозиции абз.4 § 176 УУ ФРГ «Сексуальные злоупотребления в отношении детей» были описаны развратные действия сексуального характера в отношении детей без контакта с телом жертвы, а именно: совершение в присутствии ребенка виновным лицом сексуальных действий; склонение ребенка участию в совершении сексуальных действий; воздействие на ребенка путем демонстрации порнографических иллюстраций или изображений; прослушивание магнитофонных записей порнографического содержания; проведения с ребенком бесед на соответствующие темы. Однако, по мнению У.В. Уманского и С.А. Маркунцова, данная диспозиция была сформулирована неудачно [15, с.190]. В октябре 2008 года вступил в действие Закон о трансформации Рамочного решения Совета 2004/68 / ПВД Европейского Союза от 22 декабря 2003 года о борьбе с сексуальной эксплуатацией детей и детской порнографией (OJ. EC Nr. L 13 c.44) на территории ФРГ [16, с. 17]. Однако, в соответствии с § 182 УУ ФРГ «Сексуальное насилие против молодежи», уголовной защите подлежало лицо младше 16-летнего возраста, а 
в соответствии с п. «а» ст.1 Рамочного решения Совета 2004/68/, уголовной защите подлежит ребенок - любой человек в возрасте до 18 лет. Данная коллизия была устранена в ноябре 2008 года [18.].

30 июня 2013 года вступил в силу Закон об усилении прав жертв сексуальных надругательств, [19, с.1805] предусматривающий срок исковой давности - 30 лет в случае предъявления исков о возмещении ущерба в связи с преднамеренным нарушением права на сексуальное самоопределение. 49-й Закон о внесении поправок в УУ ФРГ был принят 21 января 2015 года с целью реализация требований европейского сексуального уголовного права [20, с.10], а именно требований Директивы Европейского парламента и Совета Европы 2011/93 / ЕС от 13 декабря 2011 года «О борьбе с сексуальным насилием и сексуальной эксплуатации детей и детской порнографии».

Правительство ФРГ принимает решительные меры по противодействию сексуального насилия над детьми и подростками. Так, в 2014 году Федеральное министерство по делам семьи в целях защиты детей и молодежи в Сети Интернет запустило сеть «Нет серых зон в Интернете», деятельность которой направлено на борьбу со всеми формами сексуальной эксплуатации. 02 июля
2015 года Бундестаг Германии принял решение о создании независимой комиссии по борьбе с сексуальным насилием над детьми, деятельность которой была направлена расследование масштабов жестокого обращения с детьми в Германии, его видов и последствий. Важной вехой в сфере борьбы с сексуальным насилием в отношении детей стало создание 02 декабря 2019 года Национального совета по борьбе с сексуальным насилием в отношении детей и подростков.

\section{Зак^ючение}

Проанализировав уголовное законодательство ФРГ, мы пришли к выводу, что происшедшие изменения были продиктованы временем и острой необходимостью выработки эффективного механизма защиты детей и молодежи от сексуальных злоупотреблений. Наиболее значимые законодательные реформы для исследуемого правового института прошли в 1969, 1993, 1998, 2003, 2008, 2013, 2015, 2020 годах. Немецкий законодатель не только конкретизировал составы сексуальных преступлений против детей и молодежи и ужесточал наказания, но и создал целостную систему специализированных органов с целью профилактики и борьбы с сексуальными насилиями в отношении детей и молодежи.

\section{ЛИТЕРАТУРА}

1. Статистика сексуальных преступлений от 16.04 .2020 г. [Электронный ресурс]. URL: http://www.de.statista.Com/themen/800/sexual-und-drogendelikte/ (Дата обращения 02.01 2020).

2. ̆оханнес-Вильгельм Рёриг. Сексуальные преступления против детей: надзиратель видит «новую пропасть» от 20.01. 2020 г. [Электронный ресурс]. URL: http://www.landeszeitung.de/blog/nachrichten/politik/2683 (Дата обращения 01.02. 2020).

3. Первый закон о реформе уголовного права (1. StrRG) от 25 июня 1969 г., Бюллетень федеральных законов, часть I 1969 г. № 52 от 30 июня 1969 г., стр. 645-682;

4. Второй закон о реформе уголовного законодательства (2-й указ) от 4 июля 1969 г., Бюллетень федеральных законов, часть I 1969 г. № 56 от 10 июля 1969 г., стр. 717-742.

5. Четвертый Закон о реформе уголовного законодательства (4-я СГД) от 23 ноября 1973 г., Бюллетень федеральных законов, часть I, 1973 г., № 98 от 27 ноября 1973 г., стр. 1725-1735.

6. Двадцать седьмой закон о внесении изменений в Уголовный кодекс о внесении изменений в Уголовный кодекс - детская порнография (27 StrÄndG) oт 23 июля 1993 года, Федеральный вестник законов I 1993 № 40 от 31 июля 1993., стр. 1346-1347

7. Двадцать девятая поправка к Уголовному кодексу - статьи 175, 182 Уголовного кодекса (глава 29) от 31 мая 1994 г., Бюллетень федеральных законов, часть І, 1994 г., № 33 от 10 июня 1994 г., стр. 1168-1169.

8. Тридцатая поправка к Уголовному кодексу - Указ об ограничении половых преступлений против детей и подростков (часть 30), 23 июня 1994 г., Бюллетень федеральных законов, часть І, 1994 г., № 38, 29 июня 1994 г., стр. 34.1310.

9. ридцать третий Закон о внесении поправок в Уголовный кодекс - статьи 177-179 Уголовного кодекса (пункт 33), 1 июля 1997 г., Бюллетень федеральных законов, часть І, 1997 г., № 45, 4 июля 1997 г., страницы 1607-1608.

10. Шестой Закон о реформе уголовного законодательства (6-я СГД), 26 января 1998 г., Бюллетень федеральных законов, часть І, 1998 г., № 6, 30 января 1998 г., стр. 164-188.

11. Закон о сексуальных преступлениях и других опасных преступлениях от 26 января 1998 г., Бюллетень федеральных законов, часть I от 1998 г., номер 6 от 30 января 1998 г., стр. 160- 163.

12. Закон о принудительном исполнении от 27 апреля 1953. Бюллетень федеральных законов часть I 1953 г., № 19., 07 мая 1953 г., стр. 161-168.

13. BGH 4 StR 283/99 - решение 8 июля 1999 г. (LG Dessau); GH 1 StR 105/09 - решение от 21 апреля 2009 г. (LG Munich I) [Электронный ресурс]. URL: http://www. hrr-strafrecht.de/hrr/1/09/1-105-09.php (Дата обращения 07.02. 2020). 
14. Закон об изменении полномочий в отношении прав против сексуальной идентичности и изменении других прав от 27 декабря 2003 г., Бюллетень федеральных законов, часть I 2003 г. № 67 от 30 декабря 2003 г., стр. 3007-3012.

15. Уманский А.В., Маркунцов С.А. Основные тенденции изменений уголовно-правовых запретов особенной части Уголовного кодекса германии // Право. Журнал Высше1 школы экономики, № 1, январь-март 2013г. с 173-195.

16. Рамочное решение 2004/68/ПВД [1] Совета Европейского Союза от 22 декабря 2003 г. «0 борьбе с сексуальной эксплуатацией детей и детской порнографией» [Электронный ресурс]. URL: http://www.r-komitet.ru/media/law/razdel/221220 (Дата обращения 14.02. 2020).

17. Закон от 31 октября 2008 года о реструктуризации Рамочного решения 2004/68 / LDPE Европейского Союза от 22 декабря 2003 года по борьбе с сексуальной эксплуатацией детей и детской порнографии Вестник Федерального закона, Часть I 2008 № 50 от 4 ноября 2008 года, р $2149-2151$.

18. Закон о реализации рамочного решения Совета Европейского Союза Реализация по борьбе с сексуальной эксплуатацией детей и детской Роrnography 19 от 31 октября 2008 г., Бюллетень федеральных законов Часть I 2008 № 50 от 4 ноября 2008 г., стр. 2149-2151.

19. 20-й Закон о защите прав жертв сексуального насилия (StORMG) от 26 июня 2013 г., Бюллетень федеральных законов, часть I 2013 г. № 32 от 29 июня 2013 г., стр. 1805-1808.

20. Сорок девятый закон о внесении изменений в Уголовный кодекс - Выполнение требований Европейского сексуального уголовного права. Январь 2015 г., Бюллетень федеральных законов, часть І, номер 2, 26 января 2015 г., страницы 10-15.

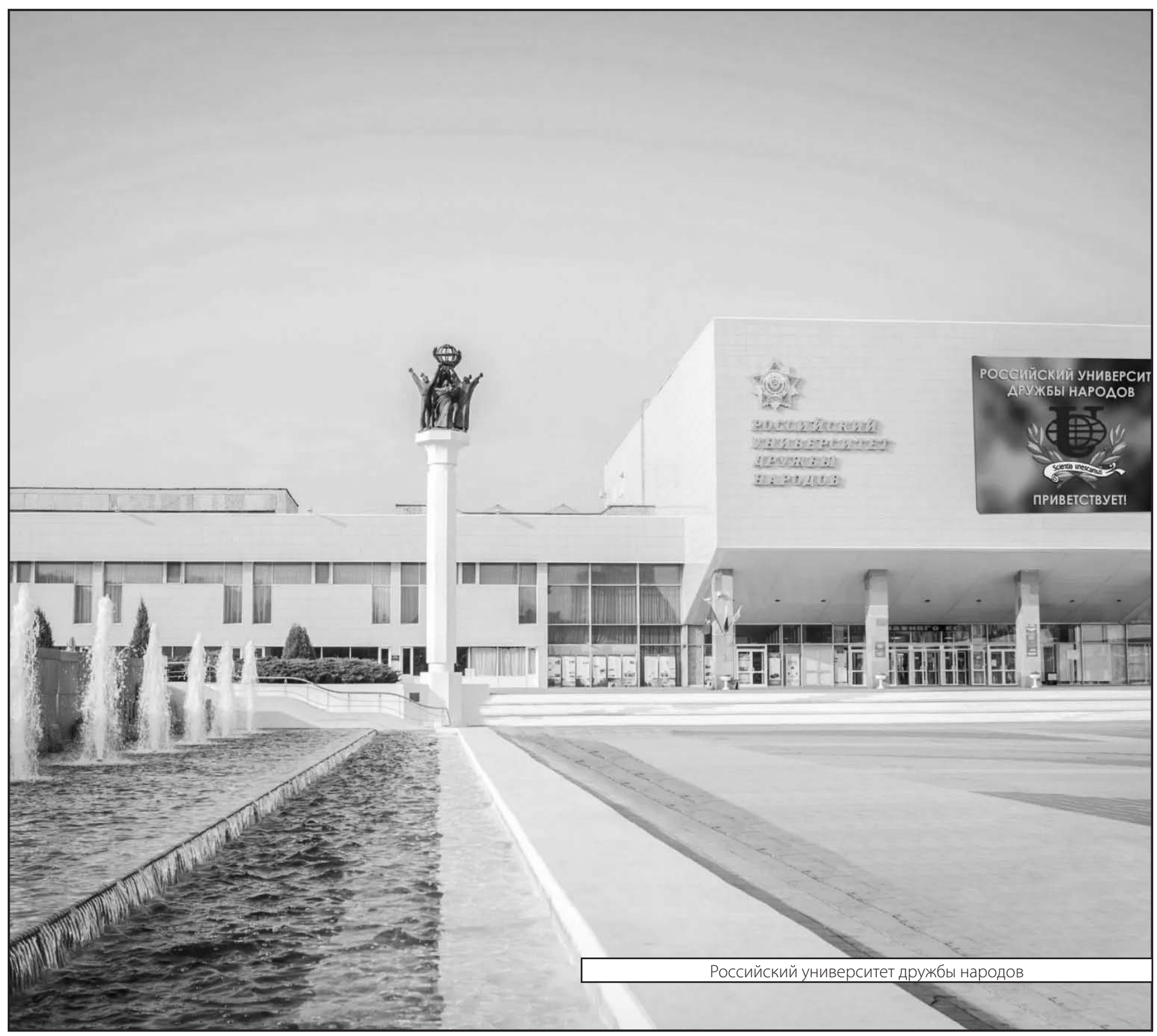

